\title{
Indices of non-specific immunity: an element of natural immunity in rabbits infected with RHD (rabbit haemorrhagic disease) virus
}

\author{
PAULINA NIEDŹWIEDZKA-RYSTWEJ' ${ }^{l}$ BEATA TOKARZ-DEPTUŁA ${ }^{l}$, \\ BEATA HUKOWSKA-SZEMATOWICZ', JOANNA DZIAEO ${ }^{1,2}$, WIESŁAW DEPTUEA ${ }^{2}$
}

${ }^{1}$ Department of Immunology, Faculty of Biology, University of Szczecin

${ }^{2}$ Department of Microbiology, Faculty of Biology, University of Szczecin

\begin{abstract}
The paper describes non-specific immunity mediated by parameters of cell and humoral immunity in rabbits experimentally infected with seven haemagglutinating strains of the rabbit haemorrhagic disease (RHD) virus, including one which is an antigenic variant of RHDV, originating from various European countries and with a different isolation time. In addition to the studies performed earlier on different strains of RHDV, this paper also shows that the immunological differences between the strains may be the core of the existence of immunotypes among RHDV.
\end{abstract}

Key words: rabbit haemorrhagic disease virus, antigenic variant, immunotypes.

(Centr Eur J Immunol 2013; 38 (2): 231-236)

\section{Introduction}

The interest in the rabbit haemorrhagic disease (RHD) virus has not decreased since the end of the last century, when in 1984 the virus was identified in China [1-4]. Since then, the virus causing viral rabbit plague among both wild and farm animals has spread worldwide, posing a severe threat to the animals that have a number of applications in various countries - from reference laboratory animals to animals hunted for [1]. The studies on biology of the RHD virus are performed worldwide, although they are hampered significantly by the impossibility of its cultivation in vitro [1-4]. Immunological studies on the virus are even less popular. Apart from a few reports that have appeared immediately after registration of the virus in China [5-7] and papers by a Portuguese team $[8,9]$, only Deptuła's team $[2-4,10$ 23] deals with immunological differentiation among the strains of the RHD virus. These studies will lead to determining the existence of immunotypes among the virus, i.e. strains differing in immunological response, defined by parameters of non-specific and specific cellular and humoral immunity, currently referred to as natural and acquired immunity. In such studies [2-4, 10-23] regarding 24 strains of RHDV originating from various, mainly European countries, also differing as to biological property, namely haemagglutination capacity, differences in the immunological profile have been recorded. This differentiation, yet only regarding antigenic properties, is also confirmed by the studies pointing to the existence of antigenic variants (RHDVa) of the RHD virus [24].

The purpose of the study was to assess the parameters of non-specific immunity, both cellular and humoral, forming elements of natural immunity, that is polymorphonuclear leukocytes (PMN) adherence capacity, absorption index and percentage of absorbing cells, spontaneous, stimulated and spectrophotometric nitro blue tetrazolium (NBT) test, stimulation index, and spontaneous and stimulated metabolic activity coefficient of granulocytes (WAMG), as well as myeloperoxidase activity in PMN cells, and lysozyme concentration and activity in serum in rabbits infected with seven haemagglutinating strains of the RHD virus, including one that is an antigenic variant of RHDV (Table 1), originating from various European countries and differing in the year of isolation. Since now, the analysed strains have not been assessed in the immunological aspect,

Correspondence: Paulina Niedźwiedzka-Rystwej, Department of Immunology, Faculty of Biology, University of Szczecin, ul. Felczaka 3c, 71-412 Szczecin, tel. +48 91444 16 05, fax +4891444 16 06, e-mail: kurp13@univ.szczecin.pl 
Table 1. Characteristics of rabbit haemorrhagic disease virus strains used for the study

\begin{tabular}{llll}
\hline No. & $\begin{array}{l}\text { Name of the Biological } \\
\text { RHD virus } \\
\text { strain }\end{array}$ & property & $\begin{array}{l}\text { Country and year } \\
\text { of isolation } \\
\text { of the RHD } \\
\text { virus strain }\end{array}$ \\
\hline 1. & $01-04$ & haemagglutinating & Austria, 2004 \\
\hline 2. & $237 / 04$ & haemagglutinating & Austria, 2004 \\
\hline 3. & V-412 & haemagglutinating & Austria, 1989 \\
\hline 4. & $05-01$ & haemagglutinating & France, 2005 \\
\hline 5. & $24 V / 89$ & haemagglutinating & Hungary, 1989 \\
\hline 6. & $1447 V / 96$ & haemagglutinating & Hungary, 1996 \\
\hline 7. & $72 V / 2003$ & $\begin{array}{l}\text { haemagglutinating } \\
\text { antigenic variant }\end{array}$ & Hungary, 2003 \\
\hline
\end{tabular}

the results obtained will enrich the results regarding immunology of RHDV strains.

\section{Material and methods}

The study involved 70 mixed-breed rabbits weighing $3.2-4.2 \mathrm{~kg}$, labelled as conventional animals, originating from a licensed farm, remaining under continuous veterinary and zoo-technical supervision [25]. During the experiment, the animals remained at the vivarium of the Department of Microbiology and Department of Immunology of the Biology Faculty at the University of Szczecin, where zoo-technical parameters were in line with the recommended Polish standards developed according to the European Union Directive as regards temperature and humidity, as well as lighting and size of cages for animals [26]. After transportation to the Department vivarium, the animals were given a two-week adaptation period. The animals were fed with all-mash rabbit feed $(16 \%$ Królik $\mathrm{z}$ Motycza) of $0.15-0.20 \mathrm{~kg} /$ day, and had unlimited access to water. The rabbits were divided into groups of infected animals (5 animals each), and each group of infected animals had a corresponding group of control animals (5 animals each). The animals in infected groups were administered intramuscularly (lower limb muscles) a dose of antigen of RHDV suspended in $1 \mathrm{ml}$ of glycerol, while rabbits in control groups received by analogy $1 \mathrm{ml}$ of glycerol. Each of the viral strains (Table 1) originated from a naturally deceased animal. These strains, in the form of liver homogenate, were used for experimental infection of rabbits, from which liver was sampled after death. Next, it was prepared as $20 \%$ homogenate purified by centrifugation at $3000 \mathrm{rpm}, 10 \%$ chloroforming for 60 minutes, and centrifugation again, and next by suspension in glycerol at the ratio of $1: 1$ [27]. All antigens prepared had the same number of viral particles determined with buoyant density in caesium chloride, within the limits of $1.34 \mathrm{~g} / \mathrm{dm}^{3}$ [27].
In blood, non-specific cellular and humoral immunity parameters were marked. And so, PMN cell adherence capacity was determined using the method of Lorente et al. [28], comprising calculation of the percentage of PMN cells adherence to glass balls, while PMN cells absorption capacity was assessed using the method developed by Brzuchowska and Ładosz, and modified by Deptuła [29], which involves calculation of absorption of reference Staphylococcus aureus $209 P$ strain by PMN cells, and which was presented as an absorption index (IP), calculated as average volume of bacteria absorbed by one PMN cell in 100 consecutive cells, and the percentage of absorbing cells (\% $\mathrm{kp}$ ), calculated as the percentage of PMN cells that reveal absorption capacity per 100 consecutive PMN cells. Furthermore, in blood, capacity for nitro blue tetrazolium reduction (NBT) was assessed in PMN cells of peripheral blood using the cytochemical method in spontaneous and simulated test according to Park et al. [30] and using spectrophotometric method (according to Raman and Poland [31]). Moreover, metabolic activity coefficient of granulocytes (WAMG) was calculated according to Grządzielska [32], while the stimulation index (IS) - according to Lechowski [33].

As regards indices of non-specific humoral immunity, the assessment of myeloperoxidase (MPO) activity was assessed using the Graham method described by Zawistowski [34], which involves marking the activity of the enzyme in PMN cells by determination of colour intensity in the histochemical reaction, whereas MPO activity coefficient was expressed using a formula according to Afanasyev [35]. In turn, lysozyme (LZM) concentration in blood serum was determined using the clot diffusion method according to Hankiewicz [36], for reference the Micrococcus lysodeikticus strain, while lysozyme activity coefficient was calculated using the formula by Szmigielski [37]. All the results obtained were subject to a statistical analysis using $t$-Student test at $p=0.05$ in the Statistica software v. 6.0, comparing the results obtained in infected and control rabbits.

\section{Results}

At first, it must be pointed out that the number of factors assessed in the area of natural immunity parameters (Table 2), namely indices of non-specific cellular immunity, was three times higher than indices of the immunity in the area of non-specific humoral immunity parameters, which resulted in more conclusions drawn on the basis of the first ones. And thus, as to results regarding non-specific cellular immunity parameters, in the case of all seven analysed strains (01-4, 237/04, V-412, 05-01, 24V/89, $1447 \mathrm{~V} / 96,72 \mathrm{~V} / 2003)$ of RHDV, more statistically significant decreases than increases were recorded, while in the case of non-specific humoral immunity parameters, the image was the reverse, namely more statistically significant increases were recorded as compared to decreases. 
Table 2. Results obtained in non-specific cell-mediated and humoral immunity in rabbits infected with 7 rabbit haemorrhagic disease virus strains

\begin{tabular}{|c|c|c|c|c|c|c|c|}
\hline $\begin{array}{l}\text { Strain } \\
\text { Parameters }\end{array}$ & $\begin{array}{l}\text { Austrian } \\
\text { 01-04 }\end{array}$ & $\begin{array}{l}\text { Austrian } \\
\text { 237/04 }\end{array}$ & $\begin{array}{l}\text { Austrian } \\
\text { V-412 }\end{array}$ & $\begin{array}{l}\text { French } \\
\text { 05-01 }\end{array}$ & $\begin{array}{l}\text { Hungarian } \\
\text { 24V/89 }\end{array}$ & $\begin{array}{l}\text { Hungarian } \\
1447 \mathrm{~V} / 96\end{array}$ & $\begin{array}{l}\text { Hungarian } \\
72 V / 2003\end{array}$ \\
\hline $\begin{array}{l}\text { PMN cells } \\
\text { adherence capacity }\end{array}$ & $\begin{array}{l}\uparrow- \\
\downarrow 24\end{array}$ & $\begin{array}{l}\uparrow- \\
\downarrow 12,24\end{array}$ & $\begin{array}{l}\uparrow 24 \\
\downarrow\end{array}$ & $\begin{array}{l}\uparrow- \\
\downarrow 8,24,36\end{array}$ & $\begin{array}{l}\uparrow 8,12,24 \\
\downarrow-\end{array}$ & $\begin{array}{l}\uparrow 12 \\
\downarrow-\end{array}$ & $\begin{array}{l}\uparrow- \\
\downarrow-\end{array}$ \\
\hline Absorption index & $\begin{array}{l}\uparrow- \\
\downarrow-\end{array}$ & $\begin{array}{l}\uparrow 8 \\
\downarrow-\end{array}$ & $\begin{array}{l}\uparrow- \\
\downarrow 8,12,24\end{array}$ & $\begin{array}{l}\uparrow- \\
\downarrow-\end{array}$ & $\begin{array}{l}\uparrow- \\
\downarrow 12,24\end{array}$ & $\begin{array}{l}\uparrow- \\
\downarrow-\end{array}$ & $\begin{array}{l}\uparrow- \\
\downarrow 24\end{array}$ \\
\hline $\begin{array}{l}\text { Percentage of } \\
\text { absorbing cells }\end{array}$ & $\begin{array}{l}\uparrow- \\
\downarrow-\end{array}$ & $\begin{array}{l}\uparrow- \\
\downarrow-\end{array}$ & $\begin{array}{l}\uparrow- \\
\downarrow 24\end{array}$ & $\begin{array}{l}\uparrow_{-} \\
\downarrow 12,24,36\end{array}$ & $\begin{array}{l}\uparrow- \\
\downarrow 8,12,24\end{array}$ & $\begin{array}{l}\uparrow_{-} \\
\downarrow_{24}\end{array}$ & $\begin{array}{l}\uparrow- \\
\downarrow 24\end{array}$ \\
\hline $\begin{array}{l}\text { NBT spontaneous } \\
\text { test }\end{array}$ & $\begin{array}{l}\uparrow- \\
\downarrow 12,24\end{array}$ & $\begin{array}{l}\uparrow- \\
\downarrow 8,12,24\end{array}$ & $\begin{array}{l}\uparrow 24 \\
\downarrow-\end{array}$ & $\begin{array}{l}\uparrow 24,36 \\
\downarrow-\end{array}$ & $\begin{array}{l}\uparrow 12,24 \\
\downarrow-\end{array}$ & $\begin{array}{l}\uparrow- \\
\downarrow 24\end{array}$ & $\begin{array}{l}\uparrow- \\
\downarrow 24\end{array}$ \\
\hline NBT stimulated test & $\begin{array}{l}\uparrow- \\
\downarrow 8,12\end{array}$ & $\begin{array}{l}\uparrow 12 \\
\downarrow 24\end{array}$ & $\begin{array}{l}\uparrow- \\
\downarrow-\end{array}$ & $\begin{array}{l}\uparrow 24 \\
\downarrow-\end{array}$ & $\begin{array}{l}\uparrow_{-} \\
\downarrow-\end{array}$ & $\begin{array}{l}\uparrow- \\
\downarrow 24\end{array}$ & $\begin{array}{l}\uparrow- \\
\downarrow 24\end{array}$ \\
\hline $\begin{array}{l}\text { NBT spectro- } \\
\text { photometric test }\end{array}$ & $\begin{array}{l}\uparrow 24 \\
\downarrow-\end{array}$ & $\begin{array}{l}\uparrow 12,24 \\
\downarrow-\end{array}$ & $\begin{array}{l}\uparrow 24 \\
\downarrow-\end{array}$ & $\begin{array}{l}\uparrow 36 \\
\downarrow-\end{array}$ & $\begin{array}{l}\uparrow- \\
\downarrow 8\end{array}$ & $\begin{array}{l}\uparrow- \\
\downarrow-\end{array}$ & $\begin{array}{l}\uparrow- \\
\downarrow-\end{array}$ \\
\hline Stimulation index & $\begin{array}{l}\uparrow 12,24 \\
\downarrow-\end{array}$ & $\begin{array}{l}\uparrow 8,12,24 \\
\downarrow-\end{array}$ & $\begin{array}{l}\uparrow- \\
\downarrow-\end{array}$ & $\begin{array}{l}\uparrow- \\
\downarrow-\end{array}$ & $\begin{array}{l}\uparrow- \\
\downarrow-\end{array}$ & $\begin{array}{l}\uparrow- \\
\downarrow-\end{array}$ & $\begin{array}{l}\uparrow- \\
\downarrow-\end{array}$ \\
\hline $\begin{array}{l}\text { Spontaneous metabolic } \\
\text { activity coefficient } \\
\text { of granulocytes }\end{array}$ & $\begin{array}{l}\uparrow- \\
\downarrow-\end{array}$ & $\begin{array}{l}\uparrow- \\
\downarrow 12,24\end{array}$ & $\begin{array}{l}\uparrow- \\
\downarrow-\end{array}$ & $\begin{array}{l}\uparrow 24 \\
\downarrow-\end{array}$ & $\begin{array}{l}\uparrow 8,24 \\
\downarrow-\end{array}$ & $\begin{array}{l}\uparrow 12 \\
\downarrow 24\end{array}$ & $\begin{array}{l}\uparrow- \\
\downarrow 24\end{array}$ \\
\hline $\begin{array}{l}\text { Stimulated metabolic } \\
\text { activity coefficient } \\
\text { of granulocytes }\end{array}$ & $\begin{array}{l}\uparrow- \\
\downarrow 8,12\end{array}$ & $\begin{array}{l}\uparrow- \\
\downarrow-\end{array}$ & $\begin{array}{l}\uparrow- \\
\downarrow-\end{array}$ & $\begin{array}{l}\uparrow 24 \\
\downarrow 8\end{array}$ & $\begin{array}{l}\uparrow 12 \\
\downarrow-\end{array}$ & $\begin{array}{l}\uparrow 12 \\
\downarrow 24\end{array}$ & $\begin{array}{l}\text { 个 - } \\
\text { v } 24\end{array}$ \\
\hline $\begin{array}{l}\text { Myeloperoxidase } \\
\text { activity }\end{array}$ & $\begin{array}{l}\uparrow- \\
\downarrow-\end{array}$ & $\begin{array}{l}\uparrow 8 \\
\downarrow-\end{array}$ & $\begin{array}{l}\uparrow 8 \\
\downarrow-\end{array}$ & $\begin{array}{l}\uparrow 24,36 \\
\downarrow-\end{array}$ & $\begin{array}{l}\uparrow 8,12 \\
\downarrow-\end{array}$ & $\begin{array}{l}\uparrow 8 \\
\downarrow 24\end{array}$ & $\begin{array}{l}\uparrow- \\
\downarrow 12,24\end{array}$ \\
\hline $\begin{array}{l}\text { Lysozyme } \\
\text { concentration }\end{array}$ & $\begin{array}{l}\uparrow 24 \\
\downarrow-\end{array}$ & $\begin{array}{l}\uparrow- \\
\downarrow 8,12\end{array}$ & $\begin{array}{l}\uparrow- \\
\downarrow-\end{array}$ & $\begin{array}{l}\uparrow 12,24 \\
\downarrow-\end{array}$ & $\begin{array}{l}\uparrow- \\
\downarrow-\end{array}$ & $\begin{array}{l}\uparrow- \\
\downarrow-\end{array}$ & $\begin{array}{l}\uparrow 24 \\
\downarrow-\end{array}$ \\
\hline Lysozyme activity & $\begin{array}{l}\uparrow 24 \\
\downarrow-\end{array}$ & $\begin{array}{l}\uparrow_{-} \\
\downarrow-\end{array}$ & $\begin{array}{l}\uparrow 12,24 \\
\downarrow-\end{array}$ & $\begin{array}{l}\uparrow 12,24 \\
\downarrow-\end{array}$ & $\begin{array}{l}\uparrow- \\
\downarrow-\end{array}$ & $\begin{array}{l}\uparrow- \\
\downarrow 8,12\end{array}$ & $\begin{array}{l}\uparrow 24 \\
\downarrow-\end{array}$ \\
\hline
\end{tabular}

Legend: Arrows represent statistically significant increase $(\uparrow)$ or decrease $(\downarrow)$ of the parameter. Numbers standing by the arrows represent the hour of testing $(0,4,8,12,24,36 h)$

In the case of haemagglutinating Austrian strain 01-4 of RHDV, increases were observed for spectrophotometric NBT test (24 h) and stimulation index (12, $24 \mathrm{~h})$, while statistically significant decreases were recorded for PMN cell adherence capacity (24 h), spontaneous NBT test (12, $24 \mathrm{~h})$, and stimulated metabolic activity coefficient of granulocytes (WAMG) $(8,12 \mathrm{~h}$ ). In turn, no changes were manifested by this strain in such factors as absorption index and absorption cell percentage, as well as spontaneous WAMG parameter. As to analysed parameters describing non-specific humoral immunity in the case of strain 01-4 of RHDV, increases at $24 \mathrm{~h}$ were observed for lysozyme concentration and activity, while MPO coefficient remained unchanged.

As to changes recorded for parameters of non-specific cellular immunity in the case of haemagglutinating Austrian strain 237/04 of RHDV, statistically significant increases were recorded for absorption index $(8 \mathrm{~h})$, stimulated NBT test
(12 h), stimulation index $(8,12,24 \mathrm{~h})$, while decrease was observed for such parameters as adherence capacity $(12,24 \mathrm{~h})$, spontaneous NBT test $(8,12,24 \mathrm{~h})$, stimulated NBT test (24 h), and spontaneous WAMG $(12,24 \mathrm{~h})$. In the case of this strain, the percentage of absorbing cells and stimulated WAMG remained unchanged. In turn, in the case of non-specific humoral immunity parameters, the strain caused an increase in MPO activity at $8 \mathrm{~h}$, decrease in lysozyme concentration at 8 and $12 \mathrm{~h}$ and no changes to lysozyme activity.

As regards Austrian haemagglutinating strain V-412 of RHDV, it must be stated that the strain caused an increase falling exclusively at $24 \mathrm{~h}$ from infection in the case of parameters such as adherence capacity, spontaneous and spectrophotometric NBT test, while decrease was recorded for absorption index $(8,12,24 \mathrm{~h})$ and the percentage of absorbing cells ( $24 \mathrm{~h}$ ). As regards stimulated NBT test, stimulation index, as well as spontaneous and stimulated 
WAMG in the case of this strain of RHDV, no statistically significant changes were recorded. In turn, in the case of non-specific humoral immunity parameters, the strain caused an increase in MPO activity at $8 \mathrm{~h}$, decrease in lysozyme activity at $12,24 \mathrm{~h}$ and no changes to concentration of the latter enzyme.

In the case of changes recorded for French haemagglutinating strain 05-01 of RHDV for non-specific cellular immunity parameters, increases were observed in spontaneous NBT test $(24,36 \mathrm{~h})$, stimulated NBT (24 h), spectrophotometric NBT (36 h), spontaneous and stimulated WAMG (24 h), while decreases were obtained for such parameters as adherence capacity $(8,24,36 \mathrm{~h})$, absorbing cell percentage $(12,24,36 \mathrm{~h})$, and stimulated WAMG $(8 \mathrm{~h})$. In this case of RHDV, no changes were recorded for the absorption index and stimulation index. In the case of changes to non-specific humoral immunity parameters with reference to strain 05-01 of RHDV, only increases were observed, and so was in the case of MPO activity coefficient at 24, $36 \mathrm{~h}$, while in the aspect of lysozyme concentration and activity at 12 and $24 \mathrm{~h}$.

As regards changes caused by Hungarian haemagglutinating 24V/89 strain of RHDV for non-specific cellular immunity parameters, statistically significant increases were recorded for adherence capacity $(8,12,24 \mathrm{~h})$, spontaneous NBT test (12, $24 \mathrm{~h})$, spontaneous WAMG (8, $24 \mathrm{~h})$ and stimulated WAMG (12 h). In turn, decreases fell at 12, 24 $\mathrm{h}$ for the absorption index, 8, 12, $24 \mathrm{~h}$ for absorbing cell percentage, and $8 \mathrm{~h}$ for spectrophotometric NBT test. No changes were recorded for stimulated NBT test and stimulation index. In turn, in the case of non-specific humoral immunity parameters of strain $24 \mathrm{~V} / 89$, increase in MPO activity was observed at $8,12 \mathrm{~h}$, and no changes for lysozyme concentration and activity.

Analysing the changes in non-specific cellular immunity parameters for Hungarian haemagglutinating 1447V/96 strain of RHDV, it must be stated that the strain caused an increase falling exclusively at $12 \mathrm{~h}$ for adherence capacity, spontaneous and stimulated WAMG, while decreases were only recorded at $24 \mathrm{~h}$ for absorbing cell percentage, NBT test, spontaneous and stimulated WAMG, while no changes were revealed for the absorption index, spectrophotometric NBT test, and stimulation index. In turn, as regards nonspecific humoral immunity parameters, $1447 \mathrm{~V} / 96$ strain showed increases in the MPO activity at $8 \mathrm{~h}$, and decreases for the same parameter at $24 \mathrm{~h}$, and lysozyme activity at $8,12 \mathrm{~h}$, as well as no changes to lysozyme concentration.

The last of the currently analysed strains of RHDV was Hungarian haemagglutinating antigenic variant 72 V/2003, which within the parameters of non-specific cellular immunity caused a special picture as changes were only recorded in the form of decrease falling exclusively at $24 \mathrm{~h}$ for parameters such as absorption index and absorbing cell percentage, NBT test, and spontaneous and stimulated WAMG. In turn, in the case of other parameters (adherence capaci- ty, spectrophotometric NBT test, stimulation index), no changes were recorded. In turn, in the case of non-specific humoral immunity parameters, antigenic variant 72V/2003 caused an increase in lysozyme concentration and activity falling at $24 \mathrm{~h}$, as well as decrease to MPO activity recorded at 12 and $24 \mathrm{~h}$.

\section{Discussion}

When analysing the obtained results, it must be stated that the currently performed experiment referring to the same immunological parameters as those evaluated in previous studies by our team [2-4, 10-23], when analysing immunogenicity of various strains of RHDV. The present study was to complete the immunological image of RHDV strains with new data, concerning new, non-analysed in this aspect, 7 strains of RHDV. It must be stated that the results of immunological studies regarding 24 strains of RHDV, including two haemagglutinating French strains (Fr-1, Fr-2) [2, 4, 18, 20] and one non-haemagglutinating antigenic variant 9905 RHDVa) [16, 27], seven haemagglutinating Polish strains (SGM, MAE, $\mathrm{KGM}, \mathrm{Z} \mathrm{D}, \mathrm{PD}, \mathrm{GSK}, \mathrm{Kr}-1$ ) and one non-haemagglutinating one (BLA) [2, 4, 14, 19, 22, 23], four haemagglutinating Czech strains (CAMP V-351, CAMP V-561, CAMP V-562, CAMP V-558) [12, 13, 23], three Italian strains (haemagglutinating BS89 and antigenic variants - haemagglutinating Vt97 and non-haemagglutinating Pv97), one English non-haemagglutinating Rainham strain, four German strains (Hagenow with variable haemagglutination capacity, haemagglutinating antigenic variants Triptis and Hartmannsdorf, and nonhaemagglutinating Frankfurt), and one Spanish non-haemagglutinating Asturias strain [17, 21, 22, 27], confirm that the diverse immunogenicity among such RHDV strains not only depends on the year and country of isolation, but also on biological properties, namely haemagglutination capacity, or formation of antigenic variants. This proves that the results can provide the basis for differentiation of immunotypes among such RHDV strains. In turn, when analysing presently obtained results for seven strains, it must be stated that in natural immunity factors, determined using the parameters of non-specific cellular immunity, principally a decrease in the parameters was recorded, while in the parameters of non-specific humoral immunity - their increase. Such picture indicates that during the infection with these strains of RHDV, activity of the immune system cells is weakened due to the activity of the virus, and at the same time, the presence of the virus in the organism causes secretion of antimicrobial substances recorded in the volume and activity of lysozyme, and MPO activity - indices of non-specific humoral immunity. Moreover, it was determined that most changes, both regarding natural immunity factors measured using the parameters of non-specific cellular and humoral immunity, regardless of the seven analysed RHDV strains, were recorded at $24 \mathrm{~h}$ from rabbit infection with such strains. Such a condition may indicate that the end of the first day of infection is the culmina- 
tion moment for the appearance of visible changes to the immune system of rabbits due to virus activity. It must also be stated that the results in the natural immunity, but measured using the parameters of non-specific cellular immunity, allowed for grouping the analysed RHDV strains depending on the number of changes caused into two groups: strains causing more changes (Austrian haemagglutinating 237/04, Hungarian haemagglutinating 24V/89, and French haemagglutinating 05-01), and strains causing fewer changes (Austrian haemagglutinating 01-04, Hungarian haemagglutinating 1447V/96, Austrian haemagglutinating V-412, as well as Hungarian haemagglutinating antigenic variant $72 \mathrm{~V} / 2003$ ). In turn, as to the immunity measured using the parameters of non-specific humoral immunity, differentiation was also recorded among the strains analysed, whereas most changes were recorded for haemagglutinating French strain 05-01, while the remaining six strains (Austrian haemagglutinating 01-04, 237/04, V-12, Hungarian haemagglutinating 24V/89, $1447 \mathrm{~V} / 96$, and Hungarian haemagglutinating antigenic variant 72V/2003) formed a group of strains causing fewer changes, which confirms previous observations of our team [2-4, 10-23] evidencing the presence of immunotypes within RHDV. It must also be stated that in the present studies, no impact was recorded of such properties as the time and country of isolation of a particular RHDV strain on their immunogenicity, namely formation of immunogroups, similarly to haemagglutination capacity of RHDV, although previous studies $[2,27]$ show that the latter property can be important for immunotype formation within RHDV. Furthermore, the results of the present study indicate that the only analysed antigenic variant 72V/2003 of RHDV caused a different image of the analysed indices as compared to the remaining six currently analysed strains of RHDV, as only decreases in the parameters analysed were observed, which confirms prior studies by our team [2-4, 10-23] on the biology of antigenic variants of RHDV. Therefore, it can be concluded that the different response of the immune system should constitute a characteristic feature of antigenic variants of RHDV, apart from the specific "nature" of binding to antibodies, belonging to one genogroup and causing high mortality, which differentiates RHDVa from classic strains of RHDV.

The paper was supported by a scientific grant of the Ministry of Science and Higher Education (no. N308 289937).

The authors declare no conflict of interest.

\section{References}

1. Abrantes J, van der Loo W, Le Pendu J, Esteves PJ (2012): Rabbit haemorrhagic disease (RHD) and rabbit haemorrhagic disease virus (RHDV): a review. Vet Res 43: 12.
2. Tokarz-Deptuła B (2009): Immunity phenomena in rabbits infected with the RHD (rabbit haemorrhagic disease) virus. Pol J Env Stud 7: 1-81.

3. Tokarz-Deptuła B, Deptuła W (2004): The immunity during immunization with the viral haemorrhagic disease (VHD) in rabbits. Centr Eur J Immunol 29: 58-62.

4. Tokarz-Deptuła B, Deptuła W, Kęsy A (2002): Rabbit plaque with a special interest in immunological phenomena. Medycyna Weter 58: 497-500.

5. Chou CT (1977): Specific surface marker of rabbit B lymphocyte - rabbit bursal equivalent lymphocyte antigen. Cell Immunol 28: 334-336.

6. Deng RT, Xu YF, Yu NX (1989): Dynamic observation of RTLA and RABELA cells in the initial stage post immunisation with RHD vaccine (in Chinese). Shanghai J Anim Sci Vet Med 5: 26-28.

7. Fradelizi DP (1973): Rabbit T-lymphocyte specific surface marker - rabbit thymus specific antigen (RTLA). Cell Immunol 24: 484-486.

8. Marques RM, Costa-E-Silva A, Aguas AP, et al. (2010): Early acute depletion of lymphocytes in calicivirus-infected adult rabbits. Vet Res Commun 34: 659-668.

9. Teixeira L, Marques RM, Aguas AP, Ferreira PG (2012): Regulatory $\mathrm{T}$ cells are decreased in acute RHDV lethal infection of adult rabbits. Vet Immunol Immunopath 148: 343-347.

10. Deptuła W, Kęsy A, Tokarz-Deptuła B, Stosik M (1997): Chosen immunological and haematological parameters in rabbits experimentally infected with RHD virus (rabbit haemorrhagic disease). Proceedings of "Veterinary microbiology - yesterday, today and tomorrow". Ed. SGGW Warsaw, Warsaw; 68-79.

11. Hukowska B, Deptuła W (2001): Absorption capacity of polymorphonuclear cells of peripheral blood in rabbits experimentally infected with different doses of VHD (viral haemorrhagic disease) - strain Fr-2. Proceedings of $4^{\text {th }}$ Conference on Molecular Biology in Diagnostics of Infectious diseases and Biotechnology. Ed. SGGW Warsaw, Warsaw; 237-242.

12. Hukowska-Szematowicz B, Deptuła W (2012): Non-specific cellular immunity in rabbits experimentally infected with four Czech strains of the rabbit haemorrhagic disease virus with different pathogenicity. Pol J Environ Stud 4: 879-892.

13. Hukowska-Szematowicz B, Deptuła W (2011): Non-specific immunity in rabbits experimentally infected with Czech strains of the rabbit haemorrhagic disease virus. Centr Eur J Immunol 36: 153-159.

14. Nahurska A, Tokarz-Deptuła B, Hukowska B, Deptuła W (2003): Selected indices of non-specific humoral immunity in rabbits experimentally infected with non-haemagglutinogenic strain of VHD (viral haemorrhagic disease) virus. Pol J Vet Sci 6: 25-27.

15. Niedźwiedzka-Rystwej P, Deptuła W (2009): Non-specific humoral immunity in rabbits infected with the selected German strains of the RHD (rabbit haemorrhagic disease) virus. Centr Eur J Immunol 34: 218-221.

16. Niedźwiedzka-Rystwej P, Deptuła W (2012): Phagocytosis of neutrophils in rabbits infected with antigenic variants of RHD (rabbit haemorrhagic disease) virus. Pol J Vet Sci 15: 143-150.

17. Niedźwiedzka-Rystwej P, Deptuła W (2009): Non-specific humoral immunity in rabbits infected with the selected German strains of the RHD (rabbit haemorrhagic disease) virus. Centr Eur J Immunol 34: 218-221.

18. Tokarz-Deptuła B, Deptuła W (2003): Non-specific cell-mediated immunity in rabbits experimentally infected with four different doses of VHD (viral haemorrhagic disease) virus, French strain Fr-2. Pol J Vet Sci 6: 64-66. 
19. Tokarz-Deptuła B, Hukowska B, Deptuła W (2003): Dynamic alterations in selected indices of non-specific cell-mediated immunity in rabbits experimentally infected with VHD (viral haemorrhagic disease) virus. Pol J Vet Sci 6: 70-73.

20. Tokarz-Deptuła B, Hukowska B, Deptuła W (2003): Ingestion capacity of PMN cells in peripheral blood of rabbits experimentally infected with VHD (viral haemorrhagic disease) virus strains originating from various biotopes. Pol J Vet Sci 6: 271-274.

21. Tokarz-Deptuła B, Hukowska-Szematowicz B, Niedźwiedzka P, Deptuła W (2006): Indices of natural and acquired immunity in rabbits experimentally infected with strains of RHD (Rabbit Haemorrhagic Disease) virus, differing in haemagglutinating properties. Proceedings of VII Mieżdunarod. Naucznoj-prakticzeskoj konf. mołodych uczenych studentow i aspirantow. Sankt-Petersburg, p. 88-97.

22. Tokarz-Deptuła B, Niedźwiedzka P, Deptuła W (2004): Dynamic alterations in serum lysozyme in rabbits experimentally infected with Polish strain PD of VHD (viral haemorrhagic disease) virus. Proceedings of IV Mieżdunarod. Naucznoj-prakticzeskoj konf. mołodych uczenych studentow i aspirantow. Sankt-Petersburg, p. 250-257.

23. Tokarz-Deptuła B, Niedźwiedzka P, Hukowska-Szematowicz B, Deptuła W (2007): Indices of immunity in rabbits experimentally infected with strains of RHD with different haemagglutination properties. Medycyna Weter 63: 1251-1254.

24. Capucci L, Fallacara F, Grazioli S, et al. (1998): A further step in the evolution of rabbit hemorrhagic disease virus: the appearance of the first consistent antigenic variant. Vir Res 58: $115-126$.

25. Anon (2006): Regulation of the Minister of Agriculture and Rural Development of 10 March 2006 on detailed conditions for maintenance of laboratory animals in experimental units, breeding units and suppliers. Polish J Laws 2006; 50: 368.

26. Anon (1987): Information and training materials of the Laboratory Animals Section, General Assembly of the Association of Agriculture Engineers and Technicians, p. 26-77.

27. Niedźwiedzka-Rystwej P, Deptuła W (2010): Non-specific immunity in rabbits infected with 10 strains of the rabbit haemorrhagic disease virus with different biological properties. Centr Europ J Biol 5: 613-632.

28. Lorente F, Fontan G, Garcia MC, Ojeda JA (1973): A simple and reproducible method to evaluate granulocyte adherence. J Immun Meth 19: 47-51.

29. Deptuła W (1991): Phagocytic activity of neutrophiles (PMN cells) in peripheral blood of bovine infected with (Bovid herpesvirus1-BHV1). Pol Arch Weter 31: 153-165.

30. Park BH, Fihring SM, Smithowiak EM (1968): Infection and nitroblue tetrazolium reduction by neutrophils A diagnostic A I D. Lancet 2: 532-538.

31. Raman U, Poland RL (1975): A new microquantitive NBT test. Ped Res 9: 334-339.

32. Grządzielska EB (1976): The study to evaluate the ability to phagocytosis of neutrophiles with the use of blue nitritetride reduction test. Doctoral thesis. Kraków, Poland.

33. Lechowski R, Lenarcik M, Degórski A, Winnicka A (1991): Serum lysozyme activity and nitroblue tetrazolium reduction test in dogs with diabetes mellitus. Zentralbl Veterinarmed A 38: 530-533.

34. Zawistowski S (1976): Histology - techniques and basics. PZWL, Warszawa.

35. Afanasyev WI, Kolot LI (1971): Izmienienije peroksydazy i cytochromoksydazy w krowi karpow Cyprinus carpio L. pri krasnuchie. Woprosy Ichtiologii 11: 940-943.
36. Hankiewicz J, Świerczek E (1975): Comparison analysis of lysozyme evaluation with agar diffusion and nefelometric method. Przegl Lek 32: 376-378.

37. Szmigielski S (1972): The analysis of up and down regulated granulocythes. Postdoctoral thesis. Warszawa, Poland. 